\title{
Relative Annual Broomweed Abundance As Related to Selected Climatic Factors
}

\section{R.K. HEITSCHMIDT}

\begin{abstract}
Regression models were developed to predict relative abundance of annual broomweeds on a Texas rangeland as a function of selected climatic factors. Based on 16 years' data, above-average precipitation in May and below-average daily maximum temperatures in April were the principal climatic factors most closely associated with heavy infestations of annual broomweeds for any given year $\left(R^{2}=0.902\right)$. Similar models developed from bimonthly and trimonthly averages were less precise than monthly averages for predicting relative abundance of annual broomweed.
\end{abstract}

Common broomweed [Xanthocephalum drancunculoides (DC.) Shinners], roundleaf broomweed (X. sphaerocephalum (Gray) Shinners vars. sphaerocephalum*, and Texas broomweed ( $X$. taxanum (DC.) $T$. and G.] comprise an annual broomweed complex indigenous to most rangelands of Texas (Gould 1975). Heavy infestations of mature annual broomweeds can seriously reduce forage production and utilization by livestock (Rittenhouse et al. 1978).

Scifres et al. (1971) studied the annual phenological development of common broomweed from College Station to Spur, Texas, from 1968 through 1970. During these 3 years. phenological progression was quite similar regardless of study

Author is assistant professor of range science. Texas A\&M University Research and Extension Center. Varnon

This report is published with approval of the Director. Texas Agricultural Experiment Station. as TA 14543.

Manuscript received September 21. 1978 location. Although some seeds germinated in the fall and survived over winter, most germinated in early spring. Rapid elongation of the primary stem occurred from early April to July with rigid floral branches formed in June and floral buds formed in July. Peak flowering occurred in September and October. At the time of flowering, plants ranged from 3 to $5 \mathrm{dm}$ tall.

Although herbicidal control of annual broomweeds has been investigated (Scifres et al. 1971; Jones et al. 1977; Beck and Sosebee 1975), only limited data are available to facilitate prediction of those years when dense annual broomweed stands will occur. It has generally been hypothesized that moist, mild falls and winters followed by wet, cool summers are conducive to heavy annual broomweed infestations (Rittenhouse et al. 1978). The objective of this study was to evaluate the relationships between selected climatic factors and annual broomweed infestations in Texas rangelands.

\section{Methods}

Relative values ranging from +2 to -2 were assigned for each year from 1961 through 1976 to describe annual broomweed abundance at the Texas Experimental Ranch (TER) near Throckmorton (Table 1). Relative values were utilized because quantitative data for all 16 years were lacking, although data were available for several years. Thus. local ranchers and researchers, who had observed annual broomweed 
Table 1. Relative abundance of annual broomweeds at the Texas Experimental Ranch from 1961 through 1976.

\begin{tabular}{lc}
\hline \hline Year & Relative abundance $^{1}$ \\
\hline 1961 & -2 \\
1962 & -2 \\
1963 & -2 \\
1964 & -2 \\
1965 & +1 \\
1966 & -2 \\
1967 & -2 \\
1968 & +2 \\
1969 & -1 \\
1970 & 0 \\
1971 & -2 \\
1972 & 0 \\
1973 & -1 \\
1974 & -2 \\
1975 & +2 \\
1976 & -1 \\
\hline
\end{tabular}

'Relative abundance values are sparse $(-2)$, light $(-1)$. moderate $(0)$, heavy $(+1)$ and extremely heavy $(+2)$

infestations during this period, were consulted before relative values were assigned for each year.

Long-term weather data from TER (Tex. Agr. Exp. Sta. 1977) were used as independent variables. First, averages and standard deviations were calculated for each of the 12 calendar months over the 16 years. Monthly parameters were: precipitation $(\mathrm{mm})$, average daily temperature $\left({ }^{\circ} \mathrm{C}\right)$, average daily maximum temperature, and average daily minimum temperature. Monthly values for any given year exceeding one standard deviation of the average for the 16 years were then assigned a relative value of either +2 or -2 . For example, average precipitation plus or minus one standard deviation for March, over the 16 years, was $39.6 \pm 28.5 \mathrm{~mm}$. In 1961, March precipitation was 71.4 $\mathrm{mm}(+2)$ and in 1963 no precipitation was received in March $(-2)$.

Next, new averages and standard deviations were calculated for those years not assigned a value of either +2 or -2 . Valucs excceding one standard deviation of this average were assigned a value of either +1 or -1 . All other years were then assigned a relative value of zero. Thus, average precipitation for March for those years within the range of $39.6 \pm 28.5 \mathrm{~mm}$ was $33.8 \mathrm{~mm}$ with a standard deviation of $13.2 \mathrm{~mm}$. Precipitation in March of 1962, 1965, and 1967 was 30.0, 17.3 and $61.2 \mathrm{~mm}$, respectively, and relative values were thus assigned of 0 , -1 and +1 , respectively.

In addition to monthly averages, relative values were determined for bimonthly and trimonthly averages to ascertain if certain average conditions for a period exceeding 1 month might be useful in predicting annual broomweed success. Average Julian date of last spring and first fall freeze and length of frost-free growing season were also calculated and relative values assigned for each year.

Correlation coefficients were then calculated, and a series of stepwise linear regression were run using maximum increase in $R^{2}$ values and backwards elimination procedures. Independent variables used to predict annual broomweed success for any given growing season were: monthly, bimonthly, and trimonthly parameters from the previous September through August of the current year; length of previous year's growing season; date of previous year's first fall freeze; and date of current year's last spring freeze.

\section{Results}

Correlation coefficients for each independent variable and relative annual broomweed abundance suggested cooler than normal temperatures were important for annual broomweed success (Table 2). Average daily maximum temperature was the only parameter significantly correlated with annual broomweed abundance $(r=-0.56, P=0.028)$, although average daily temperature and average daily minimum temperature were also negatively correlated with annual broomweed abundance. These latter two negative correlations would be expected since all three temperature variables were significantly and positively correlated with each other $(P<0.05)$.

From the stepwise regression analyses, more precise relationships were identified. Since the results were similar for both the maximum increase in $R^{2}$ and the backwards elimination procedures, only the results from the former are presented. Using a significance value of $P=0.05$ for inclusion of an independent variable in the maximum $R^{2}$ improvement model, the model based on monthly means included two variables, bimonthly means three variables, and trimonthly means one variable. Final $R^{2}$ values were $0.902,0.713$, and 0.303 , respectively. Coefficients, their estimated standard errors, and stepwise $R^{2}$ values were as follows:

$$
\begin{array}{ccc}
\hat{Y}=-0.748+0.787 X_{1} & R^{2}=0.549 \\
& ( \pm 0.198) & \\
\hat{Y}=-0.688 & +0.994 X_{1}-0.691 X_{2} & R^{2}=0.902 \\
& ( \pm 0.101) \quad( \pm 0.105) &
\end{array}
$$

where $\hat{Y}$ is predicted relative annual broomweed abundance, $X_{1}$ $=$ relative precipitation for May, and $X_{2}=$ relative average daily maximum temperature for April. Similarly, values for the model based on average conditions over a 2 -month period were:

\begin{tabular}{|c|c|c|c|c|c|c|c|c|}
\hline & $\begin{array}{l}\text { Broomweed } \\
\text { abundance }\end{array}$ & Precipitation & $\begin{array}{l}\text { Average daily } \\
\text { temperature }\end{array}$ & $\begin{array}{l}\text { Average daily } \\
\text { minimum } \\
\text { temperature }\end{array}$ & $\begin{array}{l}\text { Average daily } \\
\text { maximum } \\
\text { temperature }\end{array}$ & $\begin{array}{l}\text { Date of last } \\
\text { spring frost }\end{array}$ & $\begin{array}{l}\text { Date of first } \\
\text { fall frost }\end{array}$ & $\begin{array}{l}\text { Length of } \\
\text { previous year's } \\
\text { growing season }\end{array}$ \\
\hline Broomweed abundance & 1.000 & 0.272 & -0.409 & -0.356 & $-0.564 *$ & 0.268 & -0.212 & -0.016 \\
\hline Precipitation & & 1.000 & -0.389 & -0.100 & $-0.556 *$ & -0.060 & -0.182 & 0.000 \\
\hline $\begin{array}{l}\text { Average Daily } \\
\text { temperature }\end{array}$ & & & 1.000 & $0.787 * *$ & $0.884 * *$ & 0.056 & 0.388 & 0.158 \\
\hline $\begin{array}{l}\text { A verage daily } \\
\text { minimum temperature }\end{array}$ & & & & 1.000 & $0.603 *$ & 0.458 & 0.354 & 0.051 \\
\hline $\begin{array}{l}\text { Average daily } \\
\text { maximum temperature }\end{array}$ & & & & & 1.000 & -0.047 & 0.492 & 0.256 \\
\hline $\begin{array}{l}\text { Date of last } \\
\text { spring frost }\end{array}$ & & & & & & 1.000 & 0.035 & -0.225 \\
\hline Date of first fall frost & & & & & & & 1.000 & 0.463 \\
\hline $\begin{array}{l}\text { Length of previous } \\
\text { year's growing season }\end{array}$ & & & & & & & & 1.000 \\
\hline
\end{tabular}

$$
\hat{Y}=-1.093+\underset{( \pm 0.259)}{0.731 X_{1}} \quad R^{2}=0.380
$$

Table 2. Correlation coefficients for relative annual broomweed abundance various climatic factors based on monthly averages for precipitation (mm) and temperature $\left({ }^{\circ} \mathrm{C}\right)$, and annual averages for date of first fall frost, last spring frost, and length of growing season. 


$$
\begin{aligned}
& \hat{Y}=-1.189+0.876 X_{1}-0.577 X_{2} \\
& \pm(0.205) \quad( \pm 0.184) \\
& \hat{Y}=-1.117+\begin{array}{ccc}
0.939 X_{1}- & 0.608 X_{2} & 0.298 X_{3} R^{2} \\
( \pm 0.201) & ( \pm 0.177) & ( \pm 0.208)
\end{array} \\
& \hat{Y}=-1.117+\begin{array}{ccc}
0.939 X_{1}- & 0.608 X_{2} & 0.298 X_{3} R^{2} \\
( \pm 0.201) & ( \pm 0.177) & ( \pm 0.208)
\end{array} \\
& \begin{array}{l}
0.298 X_{3} R^{2}=0.714 \\
( \pm 0.208)
\end{array}
\end{aligned}
$$

where $X_{1}=$ relative precipitation from May 1 to June $30, X_{2}=$ relative average maximum daytime temperature from March 1 to April 30 , and $X_{3}=$ relative precipitation from July 1 to August 31 . For the model based on average conditions over a 3 -month period, relative precipitation from July 1 to September 30 was the only variable $\left(X_{1}\right)$ identified for inclusion in the model $\hat{Y}=-0.720-0.598( \pm 0.252) X_{1}$ with an $R^{2}=0.303$.

Average precipitation for May for the 16 years was $86.8 \mathrm{~mm}$ and average daily maximum temperature in April was $25.7^{\circ} \mathrm{C}$. In those years with heavy annual broomweed infestations $(+2)$, precipitation in May averaged $164.9 \mathrm{~mm}(+2)$ and average daily maximum temperatures in April averaged $23.4^{\circ} \mathrm{C}(-1)$. Entering these values into the model predicted relative annual broomweed abundance was 1.99. Similarly, in those years when annual broomweeds were sparse $(-2)$, precipitation in May averaged $53.9 \mathrm{~mm}(-1)$ and average daily maximum temperature in April averaged $26.9^{\circ} \mathrm{C}(+2)$. In this case, the model predicted relative annual broomweed abundance of -3.06 . For the bimonthly model, years with very heavy annual broomweed infestations $(+2)$ had an average precipitation from May 1 to June 30 of $221.5 \mathrm{~mm}(+2)$, an average daily maximum temperature from March 1 to April 30 of $21 .^{\circ} \mathrm{C}(-2)$ and an average precipitation from July 1 to August 30 of $165.00 \mathrm{~mm}$ (0). Entering these relative values, the model predicted a relative annual broomweed abundance of 1.98 . In those years when annual broomweeds were sparse $(-2)$, relative values for the three variables were $0,+2$, and +1 respectively, and a relative annual broomweed abundance of -2.03 was predicted. Bccause of low $R^{2}$ value for the trimonthly model, relative annual broomweed abundance was not predictable when average relative values for those years with either sparse or heavy infestations were entered.

\section{Discussion}

Based on the monthly model, above-average precipitation in May and below-average daily maximum temperatures in April are the two most important parameters influencing annual broomweed success. Furthermore, from this model, a seemingly biologically sound scenario for annual broomweed success can be developed. One would expect annual broomweeds to require only a short period of warm spring temperature to germinate. Following initial germination, a period of cooler than normal temperatures (March) would conceivably increase the probability of seedling survival. However, regardless of the number of seedlings established, abundant precipitation would be required shortly after germination and seedling establishment to facilitate growth during the period of rapid stem elongation (May).

It is doubtful that precipitation received during May is of any particular significance, other than this was the minimum time span over which the data were averaged. In actuality, it is highly probable that a model based on weekly averages would have more precisely identified those conditions whereby annual broomweed success might be assured. It follows that average precipitation from April 15 to May 15 may have provided a greater $R^{2}$ value than that based on average precipitation for the entire month of May. A similar argument can be made for the below average daily maximum temperature in April.

Since 1977 and 1978 were not included in these analyses, relative annual broomweed success in those years can be xamined as a partial "validation" of the above models. A relative value of +1 was assigned to 1977 since annual broomweed abundance at TER was moderately heavy. Climatic data from the ranch indicated precipitation in May of 1977 was $119.9 \mathrm{~mm}(+1)$ and average daily maximum temperature in April was $23.2^{\circ} \mathrm{C}(-1)$. In 1978 , annual broomweeds were nonexistent and a relative value of -2 was assigned. Precipitation in May was $49.8 \mathrm{~mm} \mathrm{(-2)}$ and average daily maximum temperature in April was $25.1^{\circ}(0)$. The monthly model predicted relative values of 1.00 and -2.68 for 1977 and 1978 , respectively. Thus, annual broomweed success in both years was predictable from the model based on precipitation received in May and average daily maximum temperature in April.

The generally accepted hypothesis that moist, mild falls and winters are conducive to abundant broomweed populations the following year is questionable. The model based on monthly averages identified precipitation in September as the eighth best independent variable, increasing $R^{2}$ by only 0.002 . No other fall precipitation values were selected prior to the model achieving a $R^{2}$ value of 1.00 . Average daily maximum temperature in October was selected as the third variable in the model. but the 0.025 increase in $R^{2}$ was not significant. Furthermore, the regression coefficient was positive, thereby suggesting that higher than normal temperatures in October facilitate annual broomweed success the following year. Similar results occurred from the model based on bimonthly means.

Additional field data collected in the fall in 1977 and spring of 1978 also suggested mild, moist fall conditions are not important to annual broomweed success the following year. Because of very dry fall conditions in 1977. I was unable to locate any appreciable number of germinating annual broomweed seedlings. Although dry conditions persisted throughout the winter and spring. I found areas by late March in 1978. in both native and recently rootplowed range, with annual broomweed seedling densities exceeding 400 plants $/ \mathrm{m}^{2}$. However. by mid-May, plant populations were eliminated because of inadequate precipitation. Precipitation in March was above normal $(+1)$ while precipitation in April was well below normal $(-2)$. From the above regression models, it can be hypothesized that normal precipitation in April and above average precipitation in May would have created a propitious situation whereby seedling survival and growth would have been maximized. Thus, even with the extremely dry fall and winter condition in 1977, the potential for heavy annual broomweed infestation in 1978 was not eliminated until the dry conditions in April were encountered.

It should be noted in light of these analyses, the linear regressions do not necessarily imply cause and effect relationships. Furthermore, although basically sound biological relationships are suggested from the analyses, quantitative ecological studies of annual broomweed germination, establishment. and survival on these rangelands are needed.

\section{Literature Cited}

Beck, D.L., and R.E. Sosebee. 1975. Fall application of herbicides for common broomweed control. J. Range Manage. 28:322

Gould, F.W. 1975. Texas plants-checklist and ecological summary. Texas Agr. Exp. Sta., College Station. 121 p.

Rittenhouse, L.R., R.H. Haas, and J.H. Brock. 1978. Annual broomweed effect on production and utilization of associated plants. Texas Agr. Exp. Sta., MP (Submitted).

Scifres, C.J., R.R. Hahn, and J.H. Brock. 1971. Phenology and control of common broomweed on Texas rangelands. J. Range Manage. 24:370-373.

Texas Agricultural Experiment Station. 1977. Beef cattle production, rangcland management and brush control. Research Center Tech. Rep. No. 77-1. Texas A\&M Univ. Agr. Res. and Ext. Center at Chillicothe-Vernon. 